\title{
Increased Liver Enzymes After Gastric Bypass Surgery
}

\author{
Marilena Durazzo ${ }^{1} \cdot$ Rinaldo Pellicano ${ }^{2,3}$ (D) \\ Published online: 14 July 2018 \\ (C) Springer Science+Business Media, LLC, part of Springer Nature 2018
}

Keywords Alanine aminostransferase $\cdot$ Gastric bypass surgery $\cdot$ Liver function tests $\cdot$ Body mass index

Dear editor,

We read with great interest the paper by Johansson et al. who evaluated, in a cross-sectional study, the clinical and laboratory characteristics of 124 patients before and at 1 year after Roux-en-Y gastric bypass (RYGBP). Among their findings, the authors reported a decrease in both gammaglutamyltransferase (GGT) and serum alanine aminotransferase (ALT) after surgery ( $p=0.011$ and $p=0.006$, respectively). Hence, they concluded that this result could be attributed to the amelioration of the non-alcoholic fatty liver disease (NAFLD) of these patients [1].

NAFLD, comprising hepatic steatosis, non-alcoholic steatohepatitis (NASH), and progressive liver fibrosis, is considered the most common liver disease in obese subjects [2]. It is well-known that serum enzyme tests are sensitive markers of liver injury but cannot be expected to differentiate one form of hepatitis from another. The main causes of hepatitis are hepatitis $\mathrm{C}$ virus and hepatitis B virus infections, NASH, excessive alcohol intake ( $>2$ units/day), autoimmune hepatitis, primary biliary cholangitis, sclerosing cholangitis, Wilson's disease, alpha ${ }_{1}$-antitrypsin deficiency, and haemochromatosis [3]. Although NAFLD/NASH has an increasing role in the context of liver diseases [4], the other etiologies remain a relevant challenge for clinicians.
Rinaldo Pellicano

rinaldo_pellican@hotmail.com

1 Department of Medical Sciences, University of Turin, Turin, Italy

2 Department of Gastroenterology, Molinette Hospital, Turin, Italy

3 Ambulatori di Gastroenterologia, Ospedale S Giovanni Battista (Molinette), S.G.A.S, Via Cavour 31, III piano, 10123 Torino, Italy
In their work, Johansson et al. considered several laboratory variables but they did not report the search for the abovementioned causes of hepatitis. Since this data could influence the future management of these patients, it represents a crucial step in the diagnostic workup.

Funding None.

\section{Compliance with Ethical Standards}

Conflict of Interest The authors declare that they have no conflict of interest.

\section{References}

1. Johansson H-E, Wåhlén A, Aldenbäck E, et al. Platelet counts and liver enzymes after gastric bypass surgery. Obes Surg. 2018;28: 1526-31.

2. Abenavoli L, Boccuto L, Masarone M, et al. Adiponectin in hepatology. Minerva Biotecnol. 2018;30:36-40.

3. Caviglia GP, Rosso C, Fagoonee S, et al. Liver fibrosis: the 2017 state of art. Panminerva Med. 2017;59:320-31.

4. Saracco GM, Evangelista A, Fagoonee S, et al. Etiology of chronic liver diseases in the northwest of Italy, 1998 through 2014. Retrospective Cohort Study. World J Gastroenterol. 2016;22:8187-93. 